\title{
Pengaruh Event Sponsorship dan Membership Terhadap Brand Image Family Futsal
}

\author{
Oleh: \\ Muhamar Kadafi ${ }^{1)}$, Hesti Mayasari ${ }^{2)}$ \\ ${ }^{1,2)}$ Fakultas Ekonomi Universitas Tamansiswa Padang \\ Davimsc3@gmail.com ${ }^{1)}$, hestimayasari@gmail.com ${ }^{2)}$
}

\begin{abstract}
Abstrak
Tujuan penelitian ini untuk mengetahui dan menganalisis pengaruh event sponsorship dan membership secara bersama-sama terhadap brand image di family futsal baik secara parsial maupun secara simultan. Metode penelitian yang digunakan adalah kuantitatif deskriptif. Teknik pengambilan sampel yang digunakan adalah probability sampling, sehingga dari populasi tersebut diambil sebanyak 81 sampel responden. Metode pengumpulan data yang digunakan adalah observasi dan kuisioner. Teknik analisis yang digunakan adalah regresi linear berganda. Hasil penelitian menunjukkan model regresi yang didapatkan adalah $\mathrm{Y}=12,193+0,166 \mathrm{X} 1+0,851 \mathrm{X} 2+$ e. Dari hasil uji $\mathrm{t}$ diperoleh bahwa : Event Sponsorship berpengaruh terhadap Brand Image dan Membership berpengaruh terhadap Brand Image. Dari hasil uji F diperoleh bahwa Event Sponsorship dan Membership berpengaruh terhadap Brand Image dan hasil analisis determinasi diperoleh angka Adjusted $R$ Square sebesar 0,483 atau sebesar 48,3\%.
\end{abstract}

Kata Kunci : Event Sponsorship, Membership dan Brand Image.

\section{PENDAHULUAN}

\section{Latar Belakang}

Konsep pemasaran terus berkembang dan berubah, dari konsep pemasaran konvensional menuju konsep pemasaran modern. Faktor-faktor seperti meningkatnya jumlah pesaing, kecanggihan teknologi dan meningkatnya edukasi mengenai pemasaran, semakin mempercepat dan memacu para pemasar untuk semakin kreatif memasarkan produknya.
Menanamkan persepsi positif bagi konsumen merupakan faktor penting dalam kesuksesan penjualan suatu usaha, maka dari itu para pebisnis perlu memberikan pengalaman yang berbeda bagi konsumen guna menyentuh sisi emosional konsumen.

Harper (2010) berpendapat bahwa pengalaman merupakan sebuah alat yang membedakan produk atau jasa. Semakin berkembangnya teknologi produk dan 
jasa maka penciptaan berbagai produk (product differentiation) sangatlah sulit, bahkan kadang kala tidak mungkin dilakukan. Kematangan sebuah produk maka kompetisi menjadi sangat ketat karena kompetitor menawarkan core product dengan fungsi dan fitur yang sama. Oleh karena itu, hanya ada sedikit perbedaan yang dapat diciptakan.

Seringkali product differentiation tergantung pada hal-hal yang bersifat subyektif dan estetik sejalan dengan usaha pemasar untuk membangkitkan emosi pelanggannya. Saat ini pelanggan menganggap fungsi, fitur, kualitas produk serta brand image yang positif sebagai hal yang biasa atau umum (Andreani, 2007). Oleh karena itu, pemasaran seharusnya tidak hanya melakukan promosi saja, tetapi juga harus mampu merelisasikan janjijanjinya secara operasional dan nyata. Produk atau jasa dapat tertanam dalam benak konsumen dengan memberikan kejutan-kejutan emosional dan membangkitkan suasana jiwa mereka dengan pengalaman yang unik.

Aspek promosi merupakan suatu sarana bagi perusahaan untuk berkomunikasi dengan para konsumennya. Melalui aktivitas promosi, perusahaan dapat mengkomunikasikan segala hal yang berkaitan dengan produk dan/atau jasa yang ditawarkannya. Banyak hal yang dapat dilakukan oleh suatu perusahaan untuk melakukan aktivitas promosi. Salah satunya adalah dengan memasang iklan di media cetak dan elektronik yang disesuaikan dengan pasar sasarannya. Disamping itu, perusahaan dapat membuat suatu program kegiatan (event) dengan tema dan sasaran serta tujuantujuan tertentu.

Perusahaan dapat juga mensponsori dan ikut berpartisipasi mensukseskan suatu kegiatan. Tentu saja, setiap kegiatan (event) dan kesertaan perusahaan (sponsorship) yang dilakukan bertujuan pula sebagai ajang promosi produk dan/atau jasa yang dimiliki perusahaan. Aktivitas promosi yang tepat sasaran dapat membangun dan memperkuat kepercayaan konsumen terhadap produk maupun jasa yang ditawarkan. Merek suatu produk yang dianggap memiliki ekuitas yang tinggi akan mempermudah perusahaan untuk merebut pangsa pasar dan membuat harga produk tersebut lebih tinggi daripada produk-produk pesaing.

Futsal adalah salah satu olahraga 
yang paling digemari di Kota Padang, hal ini terlihat dari tingginya jumlah peserta yang berpartisipasi disetiap turnamen futsal yang diadakan di Kota Padang. Pada mulanya minat yang tinggi ini tidak didukung oleh sarana (Lapangan Futsal) yang memadai, oleh karena itu olahraga futsal ini banyak menarik pebisnis untuk membangun lapangan futsal, karena dinilai memiliki segi bisnis yang menguntungkan. Seiring berjalannya waktu jumlah lapangan futsal di Kota Padang terus meningkat sehingga menimbulkan tingkat persaingan bisnis yang tinggi.

Sebagai salah satu usaha yang bergerak di bidang penyewaan lapangan futsal Family Futsal yang beralamat di jati, Kota Padang. Terus melakukan berbagai upaya untuk menghadapi persaingan bisnis lapangan futsal yang semakin ketat dengan menyediakan keunikan jenis lapangan dan pelayanan agar pelanggan mendapatkan pengalaman tak biasa ketika menggunakan jasanya. Lapangan Family Futsal memiliki jenis lapangan, manajemen dan layout yang berbeda dengan lapangan futsal lainnya. Family Futsal juga selalu mengadakan event seperti turnamen tingkat daerah dan nasional setiap tahunnya. Hal ini dilakukan bertujuan untuk memperkuat imagenya, "Sebagai tempat bermain futsal paling komplit di Kota Padang".

Tingginya tingkat persaingan penyewaan lapangan futsal di kota Padang membuat pihak pemilik lapangan futsal berupaya mempromosikan tempatnya. Dengan banyaknya pilihan tempat bermain, kualitas lapangan dan harga menjadi faktor utama pemilihan lapangan selain lokasi lapangan itu sendiri. Lokasi family futsal yang berada di tengah kota menjadi nilai lebih tersendiri. Permasalahan yang terjadi adalah sedikitnya penyewaan lapangan di jam jam tertentu., terutama jam 9 pagi hingga jam 4 sore di hari senin hingga jumat.

Bagi tim yang ingin mendapatkan harga lebih murah, family futsal menyediakan kartu membership, yang akan memberikan tim yang menjadi member jadwal bermain pasti dan tidak akan diganggu oleh tim lain. Selain jadwal yang pasti, tim yang menjadi member juga mendapatkan harga khusus oleh pengelola family futsal. Jumlah kunjungan pada family futsal terus meningkat dari tahun ke tahun. Hal ini tidak lepas dari banyaknya promosi yang 
dilakukan oleh family futsal dan turnamen yang diadakan di family futsal. Promosi yang dilakukan diantaranya dengan memberikan potongan harga bagi member, dan pada jam jam tertentu. Jam bermain yang diberikan potongan harga biasanya diberikan pada jam sepi yaitu pada jam 8 pagi sampai jam 4 sore pada hari senin sampai jum'at.

Data tersebut tergolong sedikit jika dibandingkan dengan pesaing yang ada seperti Rhafeli Futsal yang rutin mengadakan turnamen tingkat nasional setiap tahunnya. Rhafeli futsal memiliki member tetap sebanyak 127 team (Rhafeli Futsal, 2017), banyaknya member pada Rhafely Futsal dikarenakan memiliki 2 lokasi lapangan yang berada di By Pass dan Ulak Karang dimana masing masing tempat memiliki 2 lapangan. Pesaing utama lainnya adalah All Star di alaib yang memiliki 2 lapangan dengan jumlah member tetap sebanyak 78 tim (All Star Futsal; 2017).

Untuk menarik lebih banyak pengunjung, family futsal rutin mengadakan turnamen futsal dengan menggaet beberapa sponsor. Hal ini dilakukan untuk meningkatkan brand family futsal dimata penggila futsal. Untuk meningkatkan minat peserta mengikuti turnamen, family futsal menggaet sponsor ternama seperti produsen sepatu futsal adidas, speech dan lainya. Hadiah turnamen juga ditingkatkan untuk menyemangati peserta yang sedang bertanding. Kegiatan ini rutin diadakan setiap tahun agar family futsal memiliki brand yang kuat di mata penggila futsal kota Padang sebagai arena futsal yang rutin menggadakan turnamen.

Selain turnamen yang diadakan oleh famly futsal, turnamen juga dilakukan oleh pihak ke tiga dengan menggunakan lapangan family futsal sebagai tempat turnamennya. Pihak ke tiga yang dimaksud adalah pihak luar yang mengadakan turnamen seperti mahasiswa, karyawan dan pihak swasta lainnya. Pihak ke tiga yang pernah mengadakan turnamen di family futsal diantaranya adalah mahasiswa UNES, STMIK Indonesia, karyawan Bank Mandiri dan lain lain.

\section{Rumusan Masalah}

Berdasarkan uraian dari latar belakang serta diatas, maka peneliti dapat merumuskan permasalahannya sebagai berikut :

1. Apakah event sponsorship 
berpengaruh terhadap brand image di family futsal?

2. Apakah membership berpengaruh terhadap brand image di family futsal?

3. Apakah event sponsorship dan membership berpengaruh secara bersama-sama terhadap brand image di family futsal?

\section{LANDASAN TEORI}

\section{Pemasaran}

Pemasaran sebagaimana diketahui, adalah inti dari sebuah usaha. Tanpa pemasaran tidak ada yang namanya perusahaan, akan tetapi apa yang dimaksud dengan pemasaran itu sendiri orang masih belum terlalu mengerti. Pengertian pemasaran menurut Kotler (2010:8) adalah suatu proses sosial dan manajerial yang didalamnya individu dan kelompok mendapatkan apa yang mereka butuhkan dan inginkan dengan menciptakan, menawarkan dan mempertukarkan produk dengan pihak lain ".

McDaniel, Lamb, dan Hair (2011) berpendapat bahwa pemasaran adalah aktivitas, rangkaian institusi, dan proses untuk menciptakan, mengkomunikasikan, menyampaikan, dan pertukaran penawaran yang bernilai bagi konsumen, klien, mitra kerja, dan masyarakat luas. Mereka mengatakan bahwa pemasaran melibatkan lebih dari sekedar kegiatan jus yang dilakukan oleh sekelompok orang di wilayah atau area yang ditentukan. Menurut Kotler (2010) pemasaran adalah tentang mengidentifikasi dan memenuhi kebutuhan manusia dan sosial. Pemasaran adalah salah satu kunci sukses, karena ada banyak teori yang membuat bisnis semakin berkembang dan mendapatkan tujuan.

\section{Sponsorship Marketing}

Kegiatan sponsorship mencakup investasi dalam event atau causes yang bertujuan mencapai berbagai tujuan perusahaan, terutama meningkatkan kesadaran merek, memperkuat citra merek dan memperbesar volume penjualan (Nursanti, 2010). Sponsorship meliputi dua kegiatan utama, yaitu pertukaran antara sponsor (setiap merek) dan pihak yang disponsori (seperti peristiwa olahraga) dimana pihak yang terakhir menerima fee dan pihak sponsor memperoleh hak untuk dikaitkan dengan kegiatan yang disponsori dan pemasaran asosiasi oleh sponsor. Kedua kegiatan ini 
memang diperlukan jika sponsorship merupakan investasi yang berarti.

Event sponsorship adalah bentuk promosi merek yang mengikat suatu merek dengan aktivitas pertandingan atletik, hiburan, kebudayaan, sosial atau aktivitas public yang menarik lainya. Event sponsorship mempunyai banyak peluang untuk mencapai keberhasilan karena event-event itu menjangkau mereka ketika menerima pesan pemasaran serta menangkap orang-orang dalam suasana hati yang santai dan bahagia (Nursanti, 2010).

Perusahaan-perusahaan semakin mengembangkan event-event mereka sendiri daripada mensponsori eventevent yang sudah ada. Semakin banyak perusahaan yang menciptakan eventevent mereka sendiri mdan menyesuaikan event-event tersebut dengan merek-merek mereka karena dua alasan utama. Pertama, perusahaan dapat mengendalikan secara penuh event yang diselenggarakanya, sehingga tidak bergantung pada waktu yang dikenakan oleh pihak eksternal atau hambatan lainya dan juga menghilangkan masalah kesemrawutan dari banyaknya sponsor yang lain. Selain itu, event yang disesuaikan dengan mereknya juga dikembangkan agar sesuai dengan audiens sasaran merek serta untuk memaksimalkan peluang meningkatkan citra dan penjualan merek. Alasan kedua adalah kesempatan yang baik bahwa suatu event yang dirancang secara khusus akan lebih efektif dan lebih murah daripada event yang sudah ada sebelumnya.

\section{Membership}

Membership memberikan nilai bagi pemegangnya juga mempengaruhi nilai jual perusahaan. Keuntungan lain yang mudah dilihat adalah kenaikan penjualan - peningkatan keuntungan toko akibat ikatan yang dikembangkan dengan pelanggan. Poin yang akhirnya dapat ditukarkan dan konsumen mendapatan achivment sebagai pengguna tetap, membuat konsumen tersebut lebih cenderung untuk tetap menjalin hubungan dengan perusahaan (Keiza, 2016). Membership merupakan skema yang sangat baik untuk mengalahkan pesaing karena konsumen menjadi pendukung atau orang percaya dan meminta toko tersebut kepada orang lain.

Membership adalah bentuk penawaran kerjasama yang sangat 
Jurnal Manajemen dan Kewirausahaan, Volume 9, Nomor 2, Mei 2018

ISSN 2086-5031

E-ISSN 2615-3300

DOI 10.31317

menguntung dalam memperoleh penawaran harga dan pelayanan yang lebih baik dari pelanggan biasa (Andreani, 2007). Customer Relationship Management merupakan salah satu strategi dalam bidang pemasaran yang saat ini semakin banyak diimplementasikan oleh perusahaanperusahaan di Indonesia. Implementasi Customer Relationship Management banyak diterapkan pada perusahaan maskapai penerbangan, hotel, sampai perusahaan yang bergerak dalam bisnis ritel seperti Matahari Department Store dengan program kepemilikan membership card yang disebut dengan "Matahari Club Card (MCC) (Wijaya, 2009).

Berdasarkan observasi yang dilakukan oleh Wijaya (2009) yang dilakukan oleh penulis diketahui bahwa strategi customer relationship management yang dijalankan oleh penyedia bisnis jasa makanan bagi pelanggan restoran di Surabaya sebagian besar masih didominasi oleh penyediaan manfaat secara finansial. Lebih spesifik, manfaat finansial yang ditawarkan pada pelanggan adalah berupa program kartu keanggotaan (membership card program).

\section{Brand Image}

Citra merek / Brand image merupakan serangkaian asosiasi (persepsi) yang ada dalam benak konsumen terhadap suatu merek, biasanya terorganisasi menjadi suatu makna. Hubungan terhadap suatu merek akan semakin kuat jika didasarkan pada pengalaman dan mendapat banyak informasi. Citra atau asosiasi merepresentasikan persepsi yang bisa merefleksikan kenyataan yang objektif ataupun tidak. Citra yang terbentuk dari asosiasi (presepsi) inilah yang mendasari keputusan membeli bahkan loyalitas merek (brand loyalty) dari konsumen. Citra merek meliputi pengetahuan dan kepercayaan akan atribut merek (aspek kognitif), konsekuensi dari penggunaan merek tersebut dan situasi penggunaan yang sesuai, begitu juga dengan evaluasi, perasaan dan emosi yang dipresepsikan dengan merek tersebut (aspek Afektif) (Kotler, 2009).

Peter \& Olson (2009) Citra merek didefinisikan sebagai persepsi konsumen dan preferensi terhadap merek, sebagaimana yang direfleksikan oleh berbagai macam asosiasi merek yang ada dalam ingatan konsumen. Meskipun 
asosiasi merek dapat terjadi dalam berbagai macam bentuk tapi dapat dibedakan menjadi asosiasi performansi dan asosiasi imajeri yang berhubungan dengan atribut dan kelebihan merek.

Citra merek (Brand image) merupakan representasi dari keseluruhan persepsi terhadap merek dan dibentuk dari informasi dan pengalaman masa lalu terhadap merek itu. Citra terhadap merek berhubungan dengan sikap yang berupa keyakinan dan preferensi terhadap suatu merek. Konsumen yang memiliki citra yang positif terhadap suatu merek, akan lebih memungkinkan untuk melakukan pembelian (Ramadhoni, 2014)

Kotler (2010) menyatakan bahwa citra merek adalah persepsi tentang merek yang digambarkan oleh asosiasi merek yang ada dalam ingatan konsumen. Harper (2012) berpendapat citra merek adalah merupakan konsep yang diciptakan oleh konsumen karena alasan subjektif dan emosi pribadinya. Dari beberapa pendapat para ahli di atas dapat disimpulkan bahwa citra merek adalah persepsi konsumen dan preferensi terhadap merek, sebagaimana yang direfleksikan oleh berbagai macam asosiasi (persepsi) merek yang ada dalam ingatan konsumen.
Brand image atau brand description, yakni deskripsi tentang asosiasi dan keyakinan konsumen terhadap merek tertentu (Tjiptono, 2008). Citra merek meliputi pengetahuan dan kepercayaan akan atribut merek (aspek kognitif), konsekuensi dari penggunaan merek tersebut, dan situasi penggunaan yang sesuai, begitu juga dengan evaluasi, perasaan dan emosi yang diasosiasikan dengan merek tersebut (aspek afektif). Citra merek didefinisikan sebagai persepsi konsumen dan preferensi terhadap merek, sebagaimana yang direfleksikan oleh berbagai macam asosiasi merek yang ada dalam ingatan konsumen.

Berdasarkan uraian di atas dapat disimpulkan bahwa brand image merupakan serangkaian kepercayaan konsumen tentang merek tertentu sehingga asosiasi merek tersebut melekat di benak konsumen. 


\section{Gambar 1. Kerangka Konseptual}

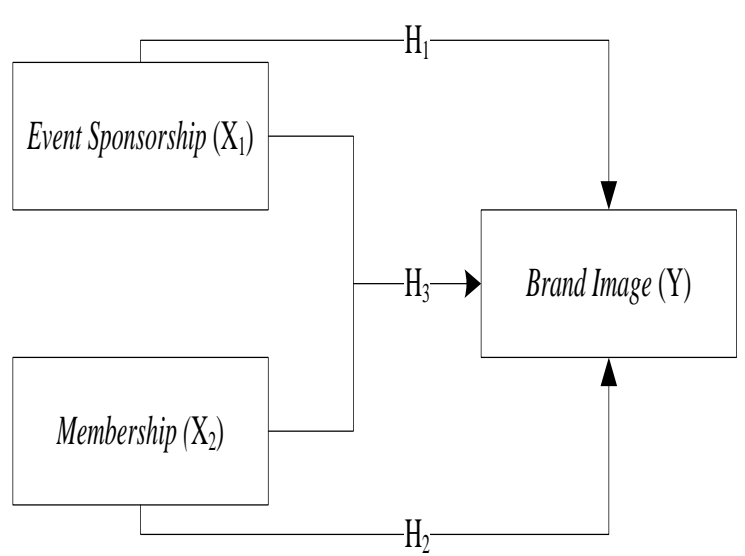

Hipotesis

$\mathrm{H}_{1}$ : Diduga event sponsorship berpengaruh signifikan terhadap brand image di family futsal.

$\mathrm{H}_{2}$ : Diduga membership berpengaruh signifikan terhadap brand image di family futsal.

$\mathrm{H}_{3}$ : Diduga event sponsorship dan membership berpengaruh signifikan terhadap brand image di family futsal.

\section{METODE PENELITIAN}

\section{Jenis Dan Metodologi Penelitian}

Metode penelitian yang dipakai dalam penelitian ini adalah metode kuantitatif, metode kuantitatif adalah metode penelitian ilmiah yang digunakan untuk mendapatkan data yang valid dengan tujuan dapat membuktikan dan mengembangkan suatu pengetahuan, sehingga dapat digunakan untuk memahami, memecahkan dan mengantisipasi masalah dalam bidang tertentu (Sugiyono, 2010).

Jenis penelitian ini adalah penelitian deskriptif, penelitian deskriptif adalah adalah salah satu jenis penelitian yang tujuannya untuk menyajikan gambaran lengkap mengenai setting sosial atau dimaksudkan untuk eksplorasi dan klarifikasi mengenai suatu fenomena atau kenyataan sosial, dengan jalan mendeskripsikan sejumlah variabel yang berkenaan dengan masalah dan unit yang diteliti antara fenomena yang diuji (Sugiyono, 2010).

Untuk keperluan analisis, peneliti mengumpulkan dan mengolah data yang diperoleh dari angket dengan cara memberikan bobot penilaian setiap jawaban pertanyaan berdasarkan skala Likert menurut Sugiyono (2010), skala Likert digunakan untuk mengukur sikap pendapat dan persepsi seseorang atau sekelompok orang tentang fenomena sosial.

\section{Indentifikasi Variabel Penelitian}

Variabel adalah suatu atribut atau sifat atau nilai dari orang, objek, atau kegiatan yang mempunyai variasi tertentu yang 
ditetapkan oleh peneliti untuk dipelajari dan ditarik kesimpulannya (Sugiyono, 2010). Variabel penelitian terdiri atas dua macam, yaitu : variabel terikat (dependent variable) atau variabel yang tergantung pada variabel lainnya yaitu brand image, dan variabel bebas (independent variable) atau variabel yang tidak tergantung pada variabel lainnya yaitu event sponsorship dan membership.

\section{Populasi}

Populasi adalah suatu kelompok yang terdiri dari objek atau subjek yang mempunyai kualitas dan karakteristik tertentu yang ditetapkan oleh peneliti untuk dipelajari dan kemudian ditarik kesimpulan (Sugiyono, 2010:17). Populasi dalam penelitian ini adalah pelanggan yang menyewa lapangan dari awal berdirinya family futsal yaitu pada tahun 2017 sebanyak 321 Team, yang terdiri dari 42 Team sebagai member tetap, dengan asumsi setiap team terdiri dari 10 orang pemain, maka populasi dalam penelitian ini adalah 420 orang (42 $\mathrm{x} 10)$.

\section{Sampel}

Sampel adalah sebagian dari populasi yang memiliki karakteristik yang sama dengan populasi. Adapun jumlah sampel dari populasi di atas dihitung dengan menggunakan rumus slovin dan didapatkan sampel sebanyak 81 responden.

\section{Jenis Data}

1. Data Primer, adalah data yang penulis peroleh langsung dari objek penelitian dengan cara mengajukan daftar pertanyaan kepada responden dan menyebarkan kuesioner mengenai event sponsorship dan membership.

2. Data sekunder, adala data yang diperoleh dari pihak perpustakaan mengenai keadaan perkembangan jumlah penyewaan lapangan futsal dari tahun ke tahun.

\section{Sumber Data}

1. Riset Lapangan (Field Researd), dalam hal ini pengumpulan data - data yang diperlukan, penulis langsung melakukan penelitian langsung pada konsumen dan memberikan pertanyaan- pertanyaan berdasarkan angket.

2. Riset Pustaka (Library Reserd), dilakukan untuk mengumpulkan bahan acuan berupa literarur-literatur dan buku-buku yang relavan untuk 
mendapatkan landasan teoritis yang akan digunakan sebagai bahan referensi dalam pembahasan dan buku - buku statistik yang berkaitan langsung dengan penelitian.

\section{Teknik Pengumpulan Data}

1. Penelitian Lapangan (Field Research), adalah teknik pengumpulan data dengan cara mengadakan peninjauan langsung ke objek penelitian, melalui :

a. Kuesioner (Angket), dalam penelitian ini kuesioner disebarkan kepada sampel yang telah ditentukan oleh peneliti, yaitu member family futsal.

b. Observasi. Observasi ini dilakukan untuk memperoleh gambaran nyata mengenai kualitas produk yang dilakukan oleh perusahaan.

2. Penelitian Kepustakaan (Library Research), adalah alat penelitian untuk meneliti objek penelitian yang digunakan sebagai data sekunder melalui teori-teori yang sudah teruji kebenarannya, dimana data ini diperoleh melalui dokumen-dokumen, buku-buku atau tulisan ilmiah yang ada kaitan dengan tema penelitian peneliti, dengan maksud untuk melengkapi data primer yang ada di lapangan.

\section{Analisa Deskriptif}

Analisis ini bermaksud untuk menggambarkan karakteristik masingmasing variabel penelitian. Dengan cara menyajikan data ke dalam tabel distribusi frekuensi, menghitung nilai pemusatan (dalam hal nilai rata-rata, median, modus); dan nilai dispersi (standar deviasi dan koefisien variasi) serta menginterpretasikannya. Analisis ini tidak menghubung-hubungkan satu variabel dengan variabel lainnya dan tidak membandingkan satu variabel dengan variabel lainnya.

\section{Uji Validitas}

Untuk menjawab permasalahan pertama dilakukan uji validitas, menurut Arikunto (2012) dikatakan bahwa validitas adalah suatu ukuran yang menunjukkan tingkat-tingkat kevalidan, atau kesahihan suatu instrumen.Suatu instrumen yang valid atau sahih mempunyai validitas yang tinggi, sebaliknya instrumen yang kurang valid memiliki validitas yang rendah. Sebuah instrumen dikatakan valid apabila mampu mengukur apa yang diinginkan. Tinggi rendahnya validitas instrumen 
menunjukkan sejauh mana data yang terkumpul tidak menyimpang dari gambaran tentang validitas yang dimaksud.

\section{Uji Reabilitas}

Ghozali (2011) mendefinisikan reliabilitas sebagai suatu instrumen yang cukup dapat dipercaya untuk digunakan sebagai alat pengumpul data karena instrumen tersebut sudah baik. Instrumen yang baik tidak akan bersifat tendensius mengarahkan responden untuk memilih jawaban tertentu. Instrumen yang sudah dapat dipercaya, yang reliabel akan menghasilkan data yang dapat dipercaya pula.

\section{Regresi Berganda}

Analisis data yang digunakan adalah dengan menggunakan analisa regresi linear berganda, dan koefisien determinasi (Ghozali, 2011), bentuk persamaan sebagai berikut :

$\mathrm{Y}=\mathrm{a}+\mathrm{b}_{1} \mathrm{X}_{1}+\mathrm{b}_{2} \mathrm{X}_{2}+\mathrm{e}$

Dimana :

$$
\begin{aligned}
\mathrm{Y}= & \begin{array}{l}
\text { variabel terikat, yaitu brand } \\
\text { image }
\end{array} \\
\mathrm{a}= & \text { nilai konstanta } \\
\mathrm{b}_{1}= & \text { koefisien parameter } \text { event } \\
& \text { sponsorship } \\
\mathrm{b}_{2}= & \begin{array}{l}
\text { koefisien parameter } \\
\text { membership }
\end{array}
\end{aligned}
$$

$$
\begin{aligned}
& \mathrm{X}_{1}=\text { variabel bebas } 1 \text {, yaitu event } \\
& \text { sponsorship } \\
& \mathrm{X}_{2}=\text { variabel bebas 2, yaitu } \\
& \text { membership } \\
& \mathrm{e}=\text { residual error }
\end{aligned}
$$

\section{Uji t}

Pengujian hipotesis secara parsial antara variabel bebas $\left(\mathrm{X}_{\mathrm{i}}\right)$ terhadap variabel tak bebas (Y), digunakan Uji Student (Uji-t), (Ghozali, 2011) sebagai berikut :

$$
\begin{aligned}
& t_{b i}=\frac{b_{i}}{S_{b i}}=\text { untuk } \mathrm{i}=1 \\
& \mathrm{~S}_{\mathrm{bi}}=\sqrt{\frac{S^{2} y: x}{\sum_{x} 2}}
\end{aligned}
$$

Dimana :

$$
\begin{array}{ll}
t_{b i} & =\text { nilai } \mathrm{t}_{\text {-hitung dari }} \\
& \text { masing-masing variabel } \\
& \mathrm{X}_{\mathrm{i}} \\
b_{i} & =\text { nilai parameter dari } \\
& \text { masing-masing variabel } \\
& \mathrm{X}_{\mathrm{i}} \\
& =\text { nilai simpangan baku } \\
S_{b i} & \text { dari masing-masing } \\
& \text { variabel } \mathrm{X}_{\mathrm{i}} \\
S^{2} y \cdot x & =\frac{J K K}{n-k-1} \\
\sum \mathrm{x}^{2} & =\sum \mathrm{x}^{2}-\frac{1}{n}\left(\sum \mathrm{X}\right)^{2}
\end{array}
$$

\section{Uji F}

Pengujian hipotesis secara serempak (simultan) antara variabel bebas $\left(\mathrm{X}_{\mathrm{i}}\right)$ terhadap variabel tak bebas (Y), digunakan Uji Fisher (Uji-F), (Ghozali, 2011) sebagai berikut : 


$$
\mathrm{F}_{\text {hitung }}=\frac{R K R}{R K K}=\frac{J K R}{\frac{2}{\frac{J K K}{N-k-1}}}
$$

Dimana :

JKR (Jumlah Kuadrat Regresi) $=b_{1}$ $\sum \mathrm{x}_{1} \mathrm{y}+\mathrm{b}_{2} \sum \mathrm{x}_{2} \mathrm{y}$

JKK (Jumlah Kuadrat Kesalahan) = $\sum \mathrm{y}^{2}-\left(\mathrm{b}_{1} \sum \mathrm{x}_{1} \mathrm{y}+\mathrm{b}_{2} \sum \mathrm{x}_{2} \mathrm{y}\right)$

\section{Koefesien Determinasi}

Koefisien determinasi (R2) pada intinya mengukur seberapa jauh kemampuan model dalam menerangkan variasi variabel dependent. Nilai koefisien determinasi adalah antara nol dan satu. Nilai R2 yang kecil berarti kemampuan variabel-variabel independent dalam menjelaskan variasi variabel dependen amat terbatas. Nilai yang mendekati satu berarti variabelvariabel independent memberikan hampir semua informasi yang dibutuhkan untuk memprediksi variasi variabel dependent (Ghozali, 2011).

\section{HASIL DAN PEMBAHASAN}

\section{Uji Deskriptif}

Tingkat capaian responden tertinggi variabel event sponsorship diperoleh item pernyataan ke 2 dengan nilai $81,98 \%$ dan terendah item pernyataan ke
6 dengan nilai 77,28\% sedangkan ratarata capaian senilai $80 \%$. Tingkat capaian responden tertinggi variabel membership diperoleh item pernyataan ke 2 dengan nilai 82,96\% dan terendah item pernyataan ke 6 dengan nilai $74,57 \%$ sedangkan rata-rata capaian senilai 78,48\%. Tingkat capaian responden tertinggi variabel brand image diperoleh item pernyataan ke 1 dengan nilai $82,96 \%$ dan terendah item pernyataan ke 8 dengan nilai $74,32 \%$ sedangkan rata-rata capaian senilai $77,86 \%$.

\section{Uji Validitas}

Berdasarkan hasil uji validitas diketahui seluruh item pernyataan variabel event sponsorship, membership dan brand image valid dengan nilai correlation berada diatas $\mathrm{r}$ tabel senilai 0,2159 .

\section{Uji Realibilitas}

Seluruh variabel penelitian dinyatakan reliable, dimana hasil perhitungan uji reliabilitas yang masing masing variabelnya menunjukan Cronbach's Alpha lebih besar dari 0,600. Hal ini berarti keseluruhan variabel 
Jurnal Manajemen dan Kewirausahaan, Volume 9, Nomor 2, Mei 2018

ISSN 2086-5031

E-ISSN 2615-3300

DOI 10.31317

dapat digunakan untuk pengolahan data

lebih lanjut

Regresi Berganda

Tabel 1. Regresi Linear Berganda

Coefficients

\begin{tabular}{|c|c|c|c|c|c|}
\hline \multirow[t]{2}{*}{ Model } & \multicolumn{2}{|c|}{ Unstandardized Coefficients } & Standardized Coefficient & \multirow[t]{2}{*}{ t } & \multirow[t]{2}{*}{ Sig. } \\
\hline & B & Std. Error & Beta & & \\
\hline \multirow{3}{*}{1} & 12,193 & 2,889 & & 4,220 & ,000 \\
\hline & , 166 & ,092 &, 17 & 1,998 &, 006 \\
\hline &, 851 & 142 & ,58 & 6,004 &, 000 \\
\hline
\end{tabular}

Sumber; Data yang Diolah Dengan SPSS v20 (2017)

Dari tabel di atas dapat ditarik persamaan regresinya sebagai berikut : $\mathrm{Y}=12,193+0,166 \mathrm{X}_{1}+0,851 \mathrm{X}_{2}+\mathrm{e}$

1) Nilai konstanta sebesar 12,193 hal ini menunjukan bahwa variabel Event Sponsorship $\left(\mathrm{X}_{1}\right)$ dan Membership $\left(\mathrm{X}_{2}\right)$ bernilai 0 maka nilai Brand Image adalah sebesar 12,193 satuan dan jika terdapat peningkatan variabel Event Sponsorship $\left(\mathrm{X}_{1}\right)$ dan Membership $\left(\mathrm{X}_{2}\right)$ maka nilai Brand Image meningkat sebesar 12,193 satuan.

2) Nilai koefisien regresi variabel Event Sponsorship sebesar 0,166, berarti bahwa jika terjadi peningkatan variabel Event Sponsorship sebesar satu satuan maka Brand Image Family Futsal akan meningkat sebesar 0,166 atau $16,6 \%$. Koefesien bernilai positif artinya antara variabel Event Sponsorship dan Brand Image berpengaruh positif. Kenaikan variabel Event Sponsorship berakibat kenaikan pada variabel Brand Image.

3) Nilai koefisien regresi variabel Membership sebesar 0,851, berarti bahwa jika terjadi peningkatan variabel Membership sebesar satu satuan maka Brand Image Family Futsal akan meningkat sebesar 0,851 atau $85,1 \%$. Koefesien bernilai positif artinya antara variabel Membership dan Brand Image berpengaruh positif. Kenaikan variabel Membership berakibat kenaikan pada variabel Brand Image.

\section{Uji T}

Uji $t$ digunakan untuk menguji apakah terdapat pengaruh yang signifikan secara individual dari variabel bebas terhadap variabel terikat. Hasil uji 
t dari penelitian ini dapat disajikan pada tabel berikut ini.

\section{Tabel 2. Uji t}

\begin{tabular}{|cc|c|c|}
\hline Model & $\mathbf{t}$ & Sig. \\
\hline & & 4,220 &, 000 \\
1 & x1 & 1,998 &, 006 \\
& x2 & 6,004 &, 000 \\
\hline
\end{tabular}

Sumber; Data yang Diolah Dengan SPSS v20

Dengan menggunakan tingkat signifikansi $0,05(\alpha=5 \%)$ dan $t$ tabel pada signifikansi 0,05 uji dua arah dengan derajat kebebasan df n-k-1 = 812-1=78 (n adalah jumlah responden dan $\mathrm{k}$ adalah jumlah variabel bebas) dengan nilai t tabel sebesar 1,990 (lihat lampiran tabel). Hasil uji t dapat dilihat pada output SPSS dari tabel 4.13. diatas diketahui sebagai berikut :

a. Nilai $\mathrm{t}$ hitung dari variabel Event Sponsorship adalah sebesar 1,998 yang nilainya lebih besar dari nilai $\mathrm{t}$ tabel sebesar 1,990, sehingga t hitung $>\mathrm{t}$ tabel. Dan nilai sig perhitungan yang diperoleh adalah sebesar 0,006 < 0,05 jadi $\mathrm{H}_{\mathrm{o}}$ ditolak $\mathrm{H}_{1}$ diterima. Dengan demikian dapat disimpulkan bahwa Event Sponsorship secara individual berpengaruh signifikan positif terhadap Brand Image.

b. Nilai $t$ hitung dari variabel Membership adalah sebesar 6,004 yang nilainya lebih besar dari nilai $\mathrm{t}$ tabel sebesar 1,990, sehingga t hitung $>\mathrm{t}$ tabel. Dan nilai sig perhitungan yang diperoleh adalah sebesar $0,000<$ 0,05 jadi $\mathrm{H}_{\mathrm{o}}$ ditolak $\mathrm{H}_{2}$ diterima. Dengan demikian dapat disimpulkan bahwa Membership secara individual berpengaruh signifikan positif terhadap Brand Image.

\section{Uji F}

Uji $F$ dilakukan dengan melihat nilai F hitung dan nilai sig. Tabel ANOVA dari output SPSS. Hasil pengujian disajikan pada tabel berikut ini.

Tabel 3. Uji F

ANOVA

\begin{tabular}{|ll|c|c|}
\hline Model & F & Sig. \\
\hline 1 & $\begin{array}{l}\text { Regression } \\
\text { Residual } \\
\text { Total }\end{array}$ & 38,409 &, $000^{\mathrm{b}}$ \\
\hline
\end{tabular}

Sumber; Data yang Diolah Dengan SPSS v20

Dari tabel tersebut diketahui nilai $\mathrm{F}$ hitung 38,409 yang lebih besar dar nilai F tabel sebesar 3,96 dan nilai sig yang dihasilkan dari perhitungan adalah 0,000 yang lebih kecil dari $\alpha$ yang digunakan sebesar 5\%. Dengan demikian dapat disimpulkan variabel Event Sponsorship $\left(\mathrm{X}_{1}\right)$ dan Membership $\left(\mathrm{X}_{2}\right)$ secara simultan / bersama-sama berpengaruh 
Jurnal Manajemen dan Kewirausahaan, Volume 9, Nomor 2, Mei 2018

ISSN 2086-5031

E-ISSN 2615-3300

DOI 10.31317

signifikan terhadap Brand Image Family

Futsal sehingga $\mathrm{H}_{\mathrm{o}}$ ditolak $\mathrm{H}_{1}$ diterima

\section{Koefesien Determinasi}

Analisa koefisien determinasi dalam regresi liniear berganda digunakan untuk mengetahui persentasi sumbangan pengaruh variabel independen yang terdiri dari Event Sponsorship $\left(\mathrm{X}_{1}\right)$ dan Membership $\left(\mathrm{X}_{2}\right)$ secara simultan terhadap Brand Image (Y).

Tabel 4. Koefesien Determinasi

\begin{tabular}{|l|c|r|r|r|}
\hline Model & $\mathbf{R}$ & $\begin{array}{c}\mathbf{R} \\
\text { Square }\end{array}$ & $\begin{array}{c}\text { Adjusted } \\
\mathbf{R} \\
\text { Square }\end{array}$ & $\begin{array}{c}\text { Std. Error } \\
\text { of the } \\
\text { Estimate }\end{array}$ \\
\hline 1 &, $704^{\mathrm{a}}$ &, 496 &, 483 & 2,63494 \\
\hline
\end{tabular}

Sumber; Data yang Diolah Dengan SPSS (2017)

Berdasarkan tabel diatas diperoleh angka Adjusted R Square sebesar 0,483 atau 48,3\%, hal ini menunjukan bahwa persentase sumbangan variabel independen Event Sponsorship $\left(\mathrm{X}_{1}\right)$ dan Membership $\left(\mathrm{X}_{2}\right)$ terhadap variabel dependen Brand Image (Y) sebesar 0,483 atau $48,3 \%$. Sedangkan sisanya sebesar 51,7\% dipengaruhi oleh variabel lain diluar penelitian ini seperti kualitas pelayanan, proses, produk dan lain lain

\section{KESIMPULAN DAN SARAN}

\section{Kesimpulan}

Berdasarkan hasil analisis dan pembahasan mengenai pengaruh Event Sponsorship $\left(\mathrm{X}_{1}\right)$ dan Membership $\left(\mathrm{X}_{2}\right)$ terhadap Brand Image (Y), maka dapat ditarik kesimpulan sebagai berikut :

1. Hasil pengujian uji $\mathrm{t}$ Event Sponsorship terhadap Brand Image didapati nilai t hitung sebesar 1,998 lebih besar dari t tabel sebesar 1,9908 dan nilai sig sebesar 0,006 lebih kecil dari 0,05 sehingga variabel Event Sponsorship berpengaruh signifikan terhadap Brand Image.

2. Hasil pengujian uji t Membership terhadap Brand Image didapati nilai t hitung sebesar 6,004 lebih besar dari t tabel sebesar 1,9908 dan nilai sig sebesar 0,000 lebih kecil dari 0,05 sehingga variabel Membership berpengaruh signifikan terhadap Brand Image.

3. Hasil pengujian uji $\mathrm{F}$ Event Sponsorship dan Membership terhadap Brand Image didapati nilai F hitung sebesar 38,409 lebih besar dari F tabel sebesar 3,96 dan nilai sig sebesar 0,000 lebih kecil dari 0,05 sehingga variabel Event Sponsorship 
dan Membership berpengaruh signifikan terhadap Brand Image.

4. Hasil analisis determinasi diperoleh angka Adjusted $R$ Square sebesar 0,483 atau sebesar $48,3 \%$. Hal ini menunjukan persentase sumbangan variabel Event Sponsorship dan Membership terhadap kepuasan pelanggan sebesar $48,3 \%$ dan sisanya dipengaruhi varibel diluar penelitian.

\section{Saran}

Berdasarkan kesimpulan di atas, dapat dikemukakan beberapa rekomendasi yang diharapkan dapat bermanfat bagi perusahaan atau pihak lain yang berkepentingan. Adapun saran yang diberikan, antara lain :

1. Bagi Family Futsal, dari hasil penelitian disarankan bagi Family Futsal untuk meningkatkan penyebaran pamflet turnamen, rutinitas turnamen dan kualitas bola yang digunakan. Hal tersebut dikarenakan berdasarkan hasil TCR merupakan item pernyataan yang mendapatkan skor terendah pada masing masing variabel yang diteliti

2. Bagi akademik, diharapkan bagi peneliti selanjutnya yang akan meneliti tentang Brand Image untuk menambah variasi variabel yang mempengaruhi Brand Image, dan objek yang di teliti diperluas tidak hanya di Family Futsal.

\section{DAFTAR PUSTAKA}

Alma, Buchari, 2009, Manajemen Pemasaran dan Pemasaran Jasa, Edisi. Revisi, Bandung: Penerbit CV. Alfabeta.

Andreani, Fransisca. 2007. Experiential Marketing (Sebuah Pendekatan Pemasaran). Jurnal Manajemen Pemasaran, Vol. 2, No. 1, p. 1-8.

Arikunto, S. 2012. Prosedur Penelitian:

Suatu Pendekatan Praktek. Jakarta: Rineka Cipta

Boyd, Harper W,dkk, 2010, Manajemen

Pemasaran, Edisi Kedua, Erlangga,. Jakarta

Emor, Keizia Laureina. 2016. The Influence Of Loyalty Program Membership Card And Customer Experience On Customer Loyalty At The Urban Gym Aston Hotel Manado Ghozali, Imam. 2011. Aplikasi Analisis Multivariate Dengan Program IBM. SPSS 19 (edisi kelima.) Semarang: Universitas Diponegoro.

Gomez, B.G., and Arranz, A.G., and Cillan, J.G., 2016, The Role of 
Loyalty Programs In Behavioral And Affevtive Loyalty, Journal of Consumer Marketing, Vol. 23, No.7: pp 387-396.

Grey, Marie, Anne dan Kim Skildum. 2006. Event Sponsorship Seri Event Management Event no. 1. Jakarta: Penerbit PPM

Kamus Besar Bahasa Indonesia, 2017.

Kotler, Philip dan Gary Armstrong. 2010. Principles of Marketing (Edisi 13). United. States of America: Pearson

Kotler dan Keller, 2012, Marketing Management Edisi 14, Global Edition.Pearson. Prentice Hall.

Maatita, Glenn Russell, 2008, Analisis Efektivitas Program Membership Card Dalam Menciptakan Loyalitas Afektif Konsumen Matahari Department Store Di Surabaya

Nursanti, Aida, 2010. Pengaruh Event Sponsorship Terhadap Brand Image Rokok A - Mild Pada PT. Hm Sampoerna Tbk. Cabang Pekanbaru

Peter dan Olson, 2006. Perilaku

Konsumen dan Strategi Pemasaran.

Consumen Behavior. Gelora Aksara Pratama. Jakarta

Peter dan Olson, 2009. Perilaku Konsumen dan Strategi Pemasaran.
Erlangga. Jakarta

Pratiwi, Made Suci, 2014, Pengaruh Citra Perusahaan, Citra Produk Dan Citra Pemakai Terhadap Keputusan Pembelian Produk Foremost Pada Distro Ruby Soho Di Singaraja, eJournal Bisma Universitas Pendidikan Ganesha Jurusan Manajemen (Volume 2 Tahun 2014).

Ramadhoni. 2015. Hubungan Antara Persepsi Terhadap Lingkungan Psikososial Kerja Dengan Komitmen Organisasi.

Serli Wijaya, 2009, Implementasi Membership Card Dan Pengaruhnya Dalam Meningkatkan Loyalitas Pengunjung Restoran Di Surabaya Stanton, William J. 2012. Prinsip Pemasaran. Jakarta: Erlangga

Sugiyono. 2014. Metode Penelitian Bisnis. Bandung: Alfabeta.

Sutisna, Edy. (2011). Sumber Daya Manusia, Edisi 3, Kencana Prenada Media. Grup, Jakarta.

Swasta, Basu dan Irawan. 2008. Manajemen Pemasaran Modern. Yogyakarta: Liberty.

Tjiptono, Fandy \& Candra Gregorius. 2008. Service, Quality and 